\title{
PRESUMED GUILTY: \\ THE GOURT OF APPEALS VERSUS SCOTT TUROW
}

\section{H. RICHARD UVILLER $\dagger$}

On November 16, 1987, a panel of the United States Court of Appeals for the Eleventh Gircuit, per curiam, handed down a thirteen page, unpublished opinion in a case entitled United States $v$. Ofshe. ${ }^{1}$ The decision was remarkable in several respects, but principally in that it expressly invited the indictment of a former Assistant United States Attorney for the crime of obstruction of justice based entirely upon conduct clearly undertaken in the interests of law enforcement and with the approval of the Department of Justice.

The case in question came on the heels of an earlier decision of the same name ${ }^{2}$ that refused to dismiss drug charges against the defendant. Ofshe had alleged that he was denied sixth amendment rights to the loyal assistance of counsel because his lawyer had served as a covert government informer during the pendency of the indictment against Ofshe. The Court of Appeals held that Ofshe had not suffered "demonstrable . . . prejudice" nor was the government's conduct "sufficiently outrageous" to offend due process. Nonetheless, the Court included in its opinion a footnote to the effect that the prosecutor and the lawyer had engaged in "reprehensible" conduct that might warrant disciplinary action. ${ }^{3}$

The prosecutor in question, Scott F. Turow, filed a motion in the Court of Appeals to amend the opinion by deleting the footnote. $\mathrm{He}$ argued that his ethical responsibilities were not at issue in that case and that public censure, with neither prior notice nor opportunity to be heard, violated his rights to due process. The motion was supported by a memorandum filed by the United States stating that the conduct in

$\dagger$ Professor of Law, Columbia University. B.A. 1951, Harvard College; L.L.B. 1953, Yale University. The author expresses appreciation to his colleagues, and especially Gerard Lynch and Peter Strauss, for helpful comments on the ideas expressed in this paper. He is grateful too for research assistance provided by Susan Shanklin.

1 No. 86-5351, (11th Gir. Nov. 16, 1987) [hereinafter Ofshe] (on file with the University of Pennsylvania Law Review).

2817 F.2d 1508 (11th Gir.), cert. denied, 108 S. Ct. 451 (1987).

3 See id. at 1516 \& n.6 ("While we have not found the government's conduct sufficiently outrageous to warrant the dismissal of his Indictment, we do believe that Glass' and Turow's conduct was reprehensible. Because the district judge is more familiar with the attorney's conduct, we assume he will refer this matter to The Attorney Registration and Disciplinary Commission . . . for appropriate action."). 
question had been approved by the Department of Justice. ${ }^{4}$ In the opinion to which I address myself here, the court not only denied Turow's motion, but expanded its prior recommendation to suggest criminal prosecution of the prosecutor.

\section{ThE OPINION}

The opinion opens with a somewhat scornful footnote, noting that the motion is merely a request by a "stranger to [the] proceedings" and expressly refraining from "comment" on whether a remedy might be available to Turow in "a properly instituted adversarial proceeding"s (whatever that might be). ${ }^{8}$ The court then rejects as "specious" Turow's contention that the ethical censure was gratuitous. The footnote in question, the court says, related to the earlier determination of the defendant's due process claim, which necessitated a "thorough review of the record." The term "specious" is next applied to Turow's argument that his conduct resulted in no violation of Ofshe's constitutional rights. "Surely," the court comments with some ire, "Turow cannot seriously contend that a prosecutor's conduct is immune from attack on ethical grounds so long as it is not so outrageous as to rise to the level of a due process violation." Last, citing a similar notation in United States $v$. Morrison, " the panel "reject[s] outright" the claim that a federal court should not comment "as it sees fit" on the "ethical shortcomings" of lawyers who practice before it.

Having thus disposed of Turow's motion in three paragraphs, the court gets down to business. In addition to their previously expressed concern for the "ethical ramifications" of Turow's conduct, the panel now expresses the "belie[f]" that Turow may have committed the federal crime known as obstruction of justice. ${ }^{8}$ The next eight pages of the opinion are devoted to reciting the facts and explaining the court's rather unusual theory of the case.

As the opinion outlines the facts, Ronald Ofshe had been indicted in Florida on a federal cocaine charge in late 1982. Mel Black, Ofshe's counsel, took Marvin Glass as co-counsel, specifically to handle communications and negotiations with the government. Glass learned that

This fact was omitted from the court's opinion.

- Ofshe, at 2 n.1.

- Turow is not a party in any conventional sense with an established "proceeding" to "institute," nor is it easy to imagine an "adversary" to his application-other than the court itself.

7449 U.S. 361, 367 (1981) (noting the "egregious behavior" of Government agents).

818 U.S.C. $\$ 1503$ (1982); see infra note 13 for the language of the provision. 
he himself was under investigation by the United States Attorney in the Northern District of Illinois, and in April, 1983, while Ofshe's case was pending in the Southern District of Florida, he approached the United States Attorney in Chicago and offered to inform on suspected drug merchants. ${ }^{\ominus}$

Turow was the Assistant United States Attorney with whom Glass met on several occasions. On June 8, 1983, Glass first told Turow about his representation of Ofshe, a possible target. While encouraging him to report matters learned from Ofshe, Turow warned Glass not to disclose any privileged communications. Glass thereafter gave Turow information about a money-laundering scheme and told Turow that Ofshe had solicited him to find a buyer for a large amount of marijuana. A few days later, with the approval of his office, Turow had the FBI equip Glass with a "body bug."10 Again-on Turow's instruction-Glass was cautioned against jeopardizing the attorney-client privilege, and no discussion of Ofshe's pending case appeared in the monitored conversations.

Turow also instructed Glass that he would have to withdraw as Ofshe's counsel at the conclusion of the investigation-presumably before the trial or other disposition of the Ofshe case. While being fitted with the hidden recording device, Glass told an FBI agent that the case against his client had been dropped, and the agent related the information to Turow, who accepted it as true. Actually, the case, which had been twice adjourned between the date Glass became an informant and the use of the electronic monitor, was alive and a further adjournment was obtained thereafter. The motions for continuance stated that plea negotiations were under way. When the parties finally appeared in court for trial, the indictment was dismissed pursuant to an agreement reached between Glass and the Miami prosecutor (who was ignorant of Glass's service to the Illinois office) to allow Ofshe to provide information to the government. For reasons that do not appear, the criminal proceedings against Ofshe were reinstituted in August.

- No criminal charges were brought on the basis of Glass's cooperation. Glass was himself convicted of racketeering and is presently serving an eight year prison sentence.

${ }^{10}$ In its undated memorandum filed in support of Turow's motion to amend the court's first opinion, the Government noted that the recorded conversation took place on June 14, 1983. The government stated that "the decisions implemented by Turow during the period in question were decisions made by the United States Attorney's Office in Chicago." The memorandum concluded: "In conducting the investigation of Ronald Ofshe, Scott F. Turow acted in good faith, and with the full knowledge and approval of the United States Attorney's Office in Chicago." Government's Memorandum In Support of Scott F. Turow's Motion To Amend Panel Opinion at 6, United States v. Ofshe, 817 F.2d 1508 (11th Gir.) (No. 86-5351), cert. denied 108 S. Ct. 451 (1987) (on file with the University of Pennsylvania Law Review). 
Notwithstanding his promise to Turow, Glass continued to represent Ofshe. When Turow heard of this, he again admonished Glass to withdraw, and when Glass stubbornly persisted, Turow informed the District Court of Glass's service, in camera, on the next court day in February, 1984. After further resistance, Glass finally withdrew in April, 1984. Black and his client did not learn of Glass's status until February, 1985, when Black was alerted by a letter from the Chief Assistant United States Attorney in the Florida office.

Having recited the facts, the Court of Appeals then expresses the belief that Turow should have foreseen that the probable result of his use of Glass as an informant would be Glass's disqualification as Ofshe's counsel. And, indeed, the record reveals that Turow understood that the direct result of his plan would be "to destroy Glass' effectiveness as counsel." From this point, the court reasons that Turow "could anticipate" one of three "scenarios."

In the first "scenario", Glass immediately moves for permission to withdraw for a fabricated reason unrelated to his status as an informant. The fabricated reason is found to be inadequate; Glass continues as counsel, and Ofshe never learns of his lawyer's true role. "The ineffective assistance for which Turow shares responsibility is perpetuated," the Court of Appeals wrote. "In effect, Turow and Glass are responsible for an involuntary waiver by Ofshe of his right to the effective assistance of counsel. Corruptly coercing a defendant to waive a constitutional right during a judicial proceeding violates section 1503."11

The second "scenario" is like the first, except that Glass tells the truth about his status and his motion to withdraw is granted. The trial court then examines Black to see if he has been tainted. If so, the trial will be delayed while Ofshe gets new counsel. The defendant may also seek dismissal on the grounds that his sixth amendment or due process rights have been violated. "These events," the court says, "would burden the court and cause an expenditure of scarce resources that would not otherwise have occurred. We believe this is the kind of burden to the administration of justice that Congress sought to prevent with section 1503."

The third "scenario" (the one that almost occurred) has Glass disobeying Turow's instructions and refusing to terminate his representation of Ofshe. To "optimize" his own interest by pumping his client, he

11 Ofshe, at 11. The text of the statute, 18 U.S.C. $\$ 1503$, is set out in note 13 , infra. The court cited United States v. Silverman, 745 F.2d 1386, 1394 (11th Cir. 1984 ) (discussing a $\S 1503$ violation in a plea situation). See also infra note 48 (discussing a lawyer's responsibility under the Code of Professional Responsibility). 
repeatedly obtains continuances on spurious grounds in the hope that he will have more time to obtain information from Ofshe and thus enhance his position with the government as its informant. He does not withdraw until after Ofshe's case goes to trial at which time his client seeks to get his case dismissed. "Again, these events singularly and collectively waste scarce judicial and parajudicial resources and impede the due administration of the court's calendar."

The court then concludes by observing that, "Turow should have reasonably foreseen that the natural and probable consequence of the success of his scheme to monitor Ofshe's conversations with Glass would be to impede the due administration of justice in violation of section 1503." In other words, any conduct by a prosecutor, a lawyer, or any other person-however lawful, even meritorious-that might foreseeably result in the granting of an otherwise unnecessary continuance $^{\mathbf{1 2}}$ of a matter pending before a federal district court, is embraced within the intent of Congress and may well amount to the commission of the crime of obstruction of justice.

\section{THE LAW}

\section{A. Concerning Criminal Conduct}

The statutory definition of the crime of obstruction of justice is a model of imprecision. ${ }^{13}$ Its discursive description has been loosened still further by judicial construction, ${ }^{14}$ until it is almost possible to say that

12 Actually, the Court does not stress the "otherwise" and it appears from the Court's own recital that the prosecution of Ofshe was hardly moving with dispatch apart from Glass's possible contribution to delay.

13 The statute states:

Whoever corruptly, or by threats of force, or by any threatening letter or communication, endeavors to influence, intimidate, or impede any grand or petit juror, or officer in or of any court of the United States, or officer who may be serving at any examination or other proceeding before any United States commissioner or other committing magistrate, in the discharge of his duty, or injures any such grand or petit juror in his person or property on account of any verdict or indictment assented to by him, or on account of his being or having been such juror, or injures any such officer, commissioner, or other committing magistrate in his person or property on account of the performance of his official duties, or corruptly or by threats or force, or by any threatening letter or communication, influences, obstructs, or impedes, or endeavors to influence, obstruct, or impede, the due administration of justice, shall be fined not more than $\$ 5,000$ or imprisoned not more than five years, or both.

18 U.S.C. $§ 1503$ (1982).

14 See, e.g., United States v. Brand, 775 F.2d 1460, 1465 (11th Cir. 1985) ("the omnibus clause [of $\S 1503$ ] is broad enough to cover any act committed corruptly, in an endeavor to impede or obstruct justice"); United States v. Rasheed, 663 F.2d 843, 852 
the statute threatens a five-year penalty for virtually any conduct during the pendency of a judicial proceeding that the government deems evasive, abusive, or inconvenient. Yet the statute has withstood attack on grounds of vagueness, ${ }^{16}$ and ordinary principles of legality dictate the marking of distinctive limits on the scope of the crime. ${ }^{16}$

The purpose of section 1503 has been described as protecting the "participants in a specific proceeding" and preventing "a miscarriage of justice in a case pending in a federal court."17 Sometimes analogized to contempt, ${ }^{18}$ the sanction against obstruction is designed to assure the availability and integrity of witnesses and physical evidence in a case in progress. In addition, many courts have stressed that the crime is one of specific intent. ${ }^{18}$ Interpretation of the word "corrupt" in the statute has somewhat modified its ordinary meaning, but conviction under section 1503 still requires evidence of either an intention to obstruct justice or a recognition that the conduct charged actually will impede or derail the progress of the case. ${ }^{20}$ And although "endeavor" as used in the statute is something less than "attempt,"21 the crime is not committed without

(9th Cir. 1981) (construing the term "corruptly" to mean an act "done with the purpose of obstructing justice"), cert. denied, 454 U.S. 1157 (1982); United States v. Ryan; 455 F.2d 728, 733 (9th Cir. 1972) ("The offense charged must be similar to those specifically enumerated in the statute . . . .").

10 See Anderson v. United States, 215 F.2d 84, 90 (6th Cir.), cert. denied, 348 U.S. 888 (1954).

${ }_{16}$ Principles of legality assure us that a crime is sufficiently well defined if it affords advance notice to potential lawbreakers. Despite appearances to the contrary, even federal criminal provisions do not empower the prosecutor or the court to cut the crime to fit the criminal. See Dunn v. United States, 442 U.S. 100, 112-13 (1979) ("[T]o ensure that a legislature speaks with special clarity when marking the boundaries of criminal conduct, courts must decline to impose punishment for actions that are not 'plainly and unmistakably' proscribed"). See also Precious Metals Assoc. v. Commodity Futures, 620 F.2d 900, 907 (1st Cir. 1980) ("[l]anguage of proscription is not deficient if it 'conveys sufficiently definite warning as to the proscribed conduct when measured by common understanding and practices." ").

17 United States v. Metcalf, 435 F.2d 754, 756 (9th Cir. 1970); see also United States v. Cuesta, 597 F.2d 903 (5th Cir.) (the "clear intent" of $\S 1503$ is "to protect individuals assisting in a federal investigation or judicial proceeding"), cert. denied, 444 U.S. 964 (1979).

${ }_{18}$ See United States v. Howard, 569 F.2d 1331, 1336 (5th Cir.), cert. denied, 439 U.S. 834 (1978).

${ }_{19}$ See, e.g., United States v. Jeter, 775 F.2d 670, 675-76 (6th Cir. 1985), cert. denied, 475 U.S. 1142 (1986); United States v. Sun Myung Moon, 718 F.2d 1210, 1236 (2d Cir. 1983), cert. denied, 466 U.S. 971 (1984); United States v. Johnson, 713 F.2d 654, 661 (11th Cir. 1983), cert. denied, 465 U.S. 1030 (1984); United States v. Simmons, 591 F.2d 206, 209-10 (3d Cir. 1979); United States v. White, 557 F.2d 233, 235 (10th Cir. 1977).

20 See United States v. Rasheed, 663 F.2d 843, 852 (9th Cir. 1981), cert. denied, 454 U.S. 1157 (1982).

21 United States v. Buffalano, 727 F.2d 50, 53 (2d Cir., 1984); see United States v. Haas, 583 F.2d 216, 220 (5th Cir. 1978) ("'endeavor' 'describes any effort or essay to accomplish the evil purpose that the section was enacted to prevent' " (quoting 
some conduct tending to achieve the intended result. ${ }^{22}$

Concerning the sorts of behavior that have been held to amount to an obstruction of justice, West's Federal Practice Digest has organized the cases into the following categories: resisting or obstructing the execution of process, preventing a witness from attending or testifying, suppressing or falsifying of evidence, obstructing or interfering with the performance of duties of ministerial officers, and obstructing or interfering with judicial proceedings. ${ }^{23}$ In this last category we find cases dealing with: attempts to influence a member of a federal grand jury, ${ }^{24}$ deliberate concealment by a defendant of his identity to prevent the presiding magistrate from gathering facts necessary to sentencing, ${ }^{25}$ making false statements to a magistrate to mislead him concerning probation status, ${ }^{26}$ concealment of subpoenaed documents, ${ }^{27}$ attempts to influence a juror, ${ }^{28}$ forging court papers, ${ }^{2 \theta}$ protesting on courthouse grounds to interfere with normal judicial proceedings, ${ }^{30}$ selling confidential transcripts of grand jury testimony, ${ }^{31}$ offering to defense counsel to fix the jury for $\$ 20,000,{ }^{32}$ manipulating the "blind draw" system of judicial assignment in bankruptcy court, ${ }^{33}$ attempting to induce an adverse witness falsely to recant his testimony, ${ }^{34}$ and giving disguised and misleading handwriting exemplars to a grand jury. ${ }^{95}$

The only decision concerning the statute's construction that was cited by the Court of Appeals in the Turow/Glass matter, United States $v$. Silverman, ${ }^{36}$ involved a lawyer who, having obtained a plea

United States v. Russell, 255 U.S. 138, 143 (1921))., cert. denied, 440 U.S. 981 (1979).

${ }_{22}$ See Buffalano, 727 F.2d at 53; United States v. Ryan, 455 F.2d 728, 734-35 (9th Cir. 1972).

${ }^{23}$ See 79 West's Federal Practice Digest 3d 245 (1986).

24 See Haas, 583 F.2d at 218.

25 See United States v. Plascencia-Orozco, 768 F.2d 1074, 1077 (9th Cir. 1985).

${ }^{26}$ See United States v. Gonzalez-Mares, 752 F.2d 1485, 1491 (9th Gir.), cert. denied, 473 U.S. 913 (1985).

${ }^{27}$ See United States v. Rasheed, 663 F.2d 843, 852 (9th Cir. 1981), cert. denied, 454 U.S. 1157 (1982).

${ }^{28}$ See United States v. Ogle, 613 F.2d 233, 239 (10th Cir. 1979), cert. denied, 449 U.S. 825 (1980).

${ }^{29}$ See United States v. London, 714 F.2d 1558, 1566-67 (11th Cir. 1983).

${ }^{30}$ See United States v. Carter, 717 F.2d 1216, 1219 (8th Cir. 1983).

31 See United States v. Howard, 569 F.2d 1331, 1335-36 (5th Cir.), cert. denied, 439 U.S. 834 (1978).

32 See United States v. Neiswender, 590 F.2d 1269, 1272 (4th Gir.), cert. denied, 441 U.S. 963 (1979).

${ }^{33}$ See United States v. August, 745 F.2d 400, 401-02 (6th Cir. 1984).

34 See United States v. Johnson, 605 F.2d 729, 729-30 (4th Gir. 1979), cert. denied, 444 U.S. 1020 (1980).

${ }^{35}$ See United States v. Beatty, 587 F. Supp. 1325, 1329-30 (E.D.N.Y. 1984).

36 745 F.2d 1386 (11th Cir. 1984) (cited in Ofshe, at 10). 
offer from the government on a criminal case, attempted to extort money from his client to "fix" the case. In sum, my scan of the cases discloses no use of the criminal sanction like the one proposed by the Court of Appeals in Turow's case.

\section{B. Concerning Professional Irresponsibility}

The American Bar Association Standards relating to the prosecution function provide: "A prosecutor should avoid the appearance or reality of a conflict of interest with respect to official duties. In some instances, as defined in codes of professional responsibility, failure to do so will constitute unprofessional conduct." ${ }^{\text {"37 }}$ If that sounds a bit Delphic, the Gode of Professional Responsibility is not much more explicit. Specifically concerning the professional responsibilities of public prosecutors, the Code says very little; the only provisions, DR 7-103 and DR 8-101, have no bearing on relations with informers or conflicted lawyers. The Code does contain a provision that quite clearly governs Glass, but that is not directly applicable to Turow. DR 5-101(A) provides: "Except with the consent of his client after full disclosure, a lawyer shall not accept employment if the exercise of his professional judgment on behalf of his client will be or reasonably may be affected by his own financial, business, property, or personal interests."38

On the question of derivative or accessorial irresponsibility, the disciplinary rules provide that a lawyer shall not "[c]ircumvent a Disciplinary Rule through actions of another."39 The verb is mystifying. Some light is shed by the only annotation construing it: a 1933 opinion of the ABA holding a municipal attorney responsible for acts of police officers under his supervision who had interviewed represented claimants against the city without the presence of their counsel.40 Apparently, the proscription of "circumvention" applies to a lawyer who directs a lay person to do what the lawyer is precluded by the Ganons from doing directly. As such, the provision resembles an agency theory more closely than a theory of derivative culpability and probably does not apply to the Turow-Glass relationship. Some may differ, but to me a theory of responsibility predicated upon procuring an innocent agent to act for one is not the same as a theory by which responsibility is derived from the culpable conduct of another. ${ }^{41}$ For the principal to be

${ }^{37}$ ABa Standards Relating to the Administration of Griminal JusTICE $\S 3-1.2$ (2d ed. 1982).

si Model Code of Professional Responsibiltty DR 5-101(A) (1982).

${ }^{39}$ Id. DR $1-102(\mathrm{~A})(2)$.

${ }^{40}$ ABA Comm. on Professional Ethics Op. 95 (1933).

4 Contradicting my view, a colleague has argued that since culpability is attribu- 
responsible for the agent's action, we must be able to say that, had he done himself what he put his agent up to doing, he would have been at fault. When (as in Turow's case) the circumstances are such that the principal (Turow) cannot do the wrong himself (having no professional duty to his agent's client) but the actor (Glass) can, whatever derivative responsibility the principal bears must be by application of the concept of accessorial attribution, not agency. At the least, the word "circumvent" in the Code makes more sense in the case of a lawyer procuring a person unbound by the Canons to do what the lawyer cannot do himself. This, however, is not Turow's case. ${ }^{42}$

A second provision of the Model Code that might be cited in support of a theory of ascribed irresponsibility-a provision that resembles the criminal statute-is broad to the point of formlessness: DR 1$102(\mathrm{~A})(5)$ says a lawyer shall not "[e]ngage in conduct that is prejudicial to the administration of justice." Another proscription of the Model Code, Canon 9, states that "A lawyer should avoid even the appearance of professional impropriety." The Disciplinary Rules and Ethical Considerations under this Canon are far afield.

\section{Discussion}

\section{A. As to the ethical question}

Since there was no suggestion of-indeed, considerable precaution against-procuring a violation of the privilege of confidentiality, the ethical question in the Turow-Glass matter is centered on the provision against attorneys allowing conflicts to develop between their own and their clients' interests. ${ }^{43}$ At the start, it should be clear that, as a government lawyer without a client, Turow could not by his own conduct offend the injunction, which is directed to the private bar. The proscription of the ABA Standards specifically addressed to the public prosecutor is not enlightening. As noted previously, Standard 3-1.2 provides: "A prosecutor should avoid the appearance or reality of a conflict of interest with respect to official duties. In some instances, as defined in codes of professional responsibility, failure to do so will constitute unprofessional conduct." Not only does it disdain to describe conflicts of

tive under both theories, my distinction is false.

12 Another example of what I call the agency theory of indirect responsibility is the state officer who procures a private party to conduct what would be an unconstitutional search and seizure had the officer done it himself.

${ }^{43}$ This precept is expressed generally in Canon 5 of the Model Code of Professional Responsibility: "A lawyer should exercise independent professional judgment on behalf of a client." Model Code of Professional Responsibility Canon 5 (1982). 
interest "with respect to official duties," but the reference to "instances" as defined in the Code, which defines conflicts in terms of responsibilities to a client, is baffling. Guessing at the meaning of this Standard, I would think it covered the case where a prosecutor had a personal or financial interest in the outcome of some matter under his official consideration, or the case where a prosecutor represented some private client against his office, or some comparable situation in which the personal, financial, or professional interest of the prosecutor threatened or appeared to threaten the independence of his public judgment. No such case remotely resembles the case at hand.

In a situation such as the one in which Turow found himself, whatever ethical breach a prosecutor can commit in the nature of an impermissible conflict must be by some sort of accessorial attribution. ${ }^{44}$ Analytically, the first question must be whether the principal, Glass, by becoming a government informant, acquired a personal interest that might impair the exercise of his independent judgment on Ofshe's behalf.

\section{Primary Irresponsibility}

The question of the ethical duties of the lawyer with unprivileged information ${ }^{45}$ about a client's prospective criminal plan is not simple, nor is the answer obvious. Also difficult is the question whether a lawyer's capacity for independent judgment on a client's behalf is fatally impaired when the lawyer is himself under suspicion by the same office that is prosecuting his client. The compound issue presented in Glass's case may be divided: (1) Does a lawyer, with nothing personally at stake, acquire a conflict if she relates to the government prospective criminal conduct that her client intends to engage in or in which the client has solicited her participation? (2) Does a lawyer who knows he is under suspicion by a prosecutorial agency become disqualified simply by reason thereof from representing any clients against that office, or against sister offices within the same administrative structure? (3) Combined, do these two situations put the lawyer in an untenable conflict and, if so, at what point in the progress of the client's case is the conflict manifest?

14 See infra notes 57-60 and accompanying text.

45 Ofshe's solicitation of Glass as a potential go-between for drug sales, see supra note 10 and accompanying text, can be deemed unprivileged on each of two grounds. First, the communication was not a consultation of a lawyer qua lawyer. See C. MCCormick, Evidence $\S 88$ (3d ed. 1984). Second, the communication was in furtherance of a proposed crime, to wit, the sale of drugs, and is therefore not privileged. See id. at $\S 95$. 


\section{a. Disqualification of the Informant Lawyer}

When a client discloses unprivileged information to his lawyer concerning a prospective crime, or solicits the lawyer's participation in a criminal scheme, the lawyer faces a serious dilemma, perhaps even a moral choice. But does the resolution necessarily threaten the lawyer's professional obligations? To remain as counsel with no disclosure does not transgress the Canons, ${ }^{46}$ but some lawyers might feel that to conceal a criminal plan, particularly if the crime is serious and the plan has some chance of immediate fruition, is a failure of social obligation. On the other hand, furnishing harmful intelligence to the adverse party is surely a serious breach of loyalty to the client, quite possibly destructive of the professional relationship. It would be entirely understandable if a lawyer, unable to dissuade her client from the criminal enterprise, and morally unable to assist even by silence, chose to withdraw from the relationship before taking her information to the authorities. Although a lawyer who took this option might be technically free of the moral squeeze resulting from a contemporary report, shedding the client and informing on him thereafter, conveying information learned during the relationship, does not really relieve the lawyer of the onus of divided allegiance.

Would it be unprofessional for a lawyer to continue as counsel and concurrently inform the government of the client's unrelated prospective criminal enterprise? It is certain that the client is not entitled to seal an attorney's lips regarding future or ongoing criminal activities, ${ }^{47}$ nor is he entitled to the faithful service of the lawyer in a criminal endeavor. ${ }^{48}$

46 See Model Code of Professional Responsibility DR 4-101(C)(3) (1982) (permitting, but not requiring, a lawyer to reveal her client's intention to commit a crime and information necessary to prevent the crime). The question may be, however, one of degree. As the Notes to the Disciplinary Rule state, "ABA Opinion 314 (1965) indicates that a lawyer must disclose even the confidences of his clients if the facts in the attorney's possession indicated beyond reasonable doubt that a crime will be committed." "Id. at n.16.

47 See id. at $n .15$ ("[A] communication by a client to his attorney in respect to the future commission of an unlawful act or to a continuing wrong is not privileged from disclosure. Public policy forbids that the relation of attorney and client should be used to conceal wrongdoing on the part of the client.")

18 The Code of Professional Responsibility, regrettably, is not as clear on this obligation as it might be. However, a number of provisions suggest that my sense is not too far off the mark. DR 7-102(A)(3) says a lawyer shall not "[c]onceal or knowingly fail to disclose that which he is required by law to reveal." While the law might not require that lawyers (or anyone else) disclose what they know of crimes-in-the-making, but see supra note 46 , some state and federal statutes do penalize failure to assist law enforcement when asked. DR 7-102(A)(7) prohibits a lawyer from counselling or assisting her client in known illegal or fraudulent conduct. DR 7-102(B)(1) expressly requires the lawyer to reveal "fraud" committed by an unrepentant client insofar as the privilege allows. While debates have not yet allowed the concept to be expanded to 
While the ordinary citizen may be under no obligation spontaneously to report crimes to the government and misprision has gone the way of the dodo bird ${ }^{48}$ (if indeed it ever flourished in our jurisprudence), some (like me) would argue that the lawyer's obligation to the administration of justice is higher and includes the duty to inform appropriate agencies of serious and imminent criminal conduct that comes to the lawyer's attention outside the limits of confidential professional service. ${ }^{50}$ Obedience to this imperative, in my view, deprives the client of no entitlement and therefore does not violate ethical norms.

To some, perhaps, this moral or professional obligation to assist in the work of the criminal justice system seems onerous to the individual attorney and antithetical to the role of lawyers in our society generally. Many lawyers-and doubtless a number of clients-put a high value on complete fidelity. When a lawyer takes a client, the myth runs, she creates a relationship with bonds stronger than blood or sex. Trust is the rock and absolute commitment is the mortar. In this view, betrayal during or after the relationship, within or outside the Code's definition of "secret" and "confidences"si is anathema, a threat to the very nature of an attorney-client unit.

But to others, myself included, this myth seems a romantic and wishful construct. From a pragmatic standpoint if no other, a lawyer who is actually solicited to participate in a criminal conspiracy might wish to dissociate herself from the client's scheme more definitively than simply by declining the invitation to join. To some lawyers, moreover, it is important to retain emotional or moral ties to the law enforcement side of the administration of justice. If such a lawyer should bring the criminal overture to the government's attention, are all her professional ties to the client necessarily torn? It would seem that the client, blissfully ignorant of the betrayal, suffers no loss of confidence, nor should he, regarding those matters in which he is entitled to the lawyer's full devotion.

Where then is the ethical breach? Is it an internal weakening of the lawyer's commitment? Does the lawyer feel disabled by her own split role? This would seem to be an individual matter: some lawyers might be unable to devote full effort to the client they had informed against; but surely some lawyers could continue to perform effectively

cover serious crimes generally, it is difficult to draw a principled distinction.

49 See 2 W. LaFave \& A. Scotr, Substantive Criminal Law $\S 6.9$ (1986).

${ }^{30}$ In this connection, it is interesting to note that Rule 1.6 of the ABA Model Rules of Professional Conduct authorize attorneys to reveal even "information relating to the representation" to the extent it may be necessary to prevent the client from committing a crime that may result in major physical injury.

${ }^{51}$ Model Code of Professional Responsibility DR 4-101(a) (1982). 
and vigorously in the case at hand notwithstanding the information passed to the prosecutor behind the client's back about an unrelated crime-in-contemplation. After all, many effective criminal lawyers continue to render full professional value to clients they personally despise. $^{62}$

The problem is compounded-perhaps for many the quality of the relationship is changed significantly-if the lawyer undertakes to amplify the information rendered against the client by sustained or electronically-assisted surveillance. Surely, at some point during such covert activity, the lawyer's loyalty tips irretrievably and the fiduciary relationship becomes untenable even for the most adept double agent. But, to my way of thinking, the addition of a recording device in itself does not necessarily alter the balance between client fidelity and social obligation.

\section{b. Disqualification of the Suspected Lawyer}

A lawyer who is the target of a prosecutorial investigation might be tempted to sell out the interests of the client to obtain a personal advantage with his own adversary. Even if the lawyer had never made an approach, even if he had no unprivileged information to deliver, the fact that he was himself under suspicion might be thought to tempt him to buy favor at his client's expense. It may be wrong to assume that prosecutorial agencies are so mercurial that they would abandon their interest in a lawyer's misdeeds in exchange for some betrayal of the client's affairs by the lawyer. It may be error to think that lawyers are so craven that, at any hint that government suspicion was turned on them, their adversary zeal would wither. But, if we believe (as we must) that prosecutors are inveterate bargainers, and (as we often do) that defense lawyers are canny mollifiers and favor curriers, perhaps we must acknowledge that the situation is, at least, pregnant with appearances of conflict of interest. And, as the Code of Professional Responsibility continues to insist, appearances of injustice are as bad as actual transgression. ${ }^{\mathbf{3}}$

Yet the implications of this conclusion are disturbing. It is probably fair (though disheartening) to suppose that at any given time several lawyers who practice at the criminal bar are under suspicion-if not active investigation-by some prosecutorial agency. They probably

62 I mention this only to illustrate the point that effective professional service does not necessarily require loyalty and support across the board.

"Canon 9 states: "A Lawyer Should Avoid Even the Appearance of Professional Impropriety." Model Code of Professional Responsibility Canon 9 (1982). 
know of the prosecutor's interest in their affairs. And, they are likely to be lawyers with more than a few pots on the stove. Can it be that this segment of the bar is automatically disqualified from practice in the county of their peril, or if the jeopardy is federal, from appearing against the government in any district? One can hardly imagine that even the most conscientious lawyer would so construe his ethical obligations and it seems unlikely that even the most aggressive prosecutor would insist on his target's de facto suspension during the pendency of the investigation. Moreover, were it otherwise and if the practice matched the abstract illusion of unethical conflict, it would be far too easy for the vindictive or timorous prosecutor to remove his most vigorous adversary from his courtrooms by the simple device of initiating an investigation into the lawyer's affairs. Life can not be that accommodating, even for prosecutors.

\section{c. Disqualification of the Suspected Lawyer Who Informs}

Putting together the two possible disqualifications, a lawyer under suspicion serving as a continuing covert source of incrimination against a client provides the makings of an ipso facto conflict. There are simply too many ways, too many occasions, where the lawyer's interest in obtaining material favorable to the government can interfere with her devotion to the client's interest in a favorable disposition of his case. The only hard question in these circumstances is just when during the pendency of the client's case the lawyer must surrender the role of counsel.

The simple answer to the hard question is: disqualification is instantaneous-the roles are incompatible from the outset. Perhaps. But to me, at least, this proposition is not self-evident. Where the incriminating material is not learned by the lawyer in the course of rendering legal service, I do not see how the lawyer is in a position different from that of any other trusted associate of the criminally inclined client. And just as the Constitution affords no protection against the infidelity of trusted comrades (as Justice Stewart once reminded us) ${ }^{54}$ the lawyer serving as a conduit for unprivileged intelligence offends no canon of professional obligation. ${ }^{56}$

64 Hoffa v. United States, 385 U.S. 293, 302 (1966) (noting that the fourth amendment provides no protection of "a wrongdoer's misplaced belief that a person to whom he voluntarily confides his wrongdoing will not reveal it").

s5 I have elsewhere expressed the opinion that secret surveillance by the infiltration of a trusted associate is a fourth amendment event and should have appropriate, judicially supervised, sanctions. See Uviller, Evidence from the Mind of the Criminal Suspect: A Reconsideration of the Current Rules of Access and Restraint, 87 Colum. L. REv. 1137, 1209-12 (1987). Were the law as it should be, the use of a lawyer would be no different than the use of any other spy. And so it should be today when covert 
It might be asserted that the split role of the lawyer-informant disserves the profession by undermining public confidence in the special fidelity expected of lawyers. To this, I would have to answer from an undefended perspective. First, I have my doubts concerning actual public expectations from lawyers (at least that segment of the public that might be affected by counsel's defection probably trusts the lawyers less than the bar would like to believe). But more important, I believe the profession can only gain in public estimation by demonstrating its sense of obligation to the social interests of obedience to law. Even if some social value might be found in public belief in the lawyer's insuperable loyalty, other values trump the importance of sphinx loyalty. ${ }^{56}$ At the margin, where privilege does not operate, the lawyer should be not only a good citizen, but the "officer" of the system he often claims to be.

So it seems to me that, at least for some period of time, even a lawyer who is herself under a cloud, who discovers that her client is engaged or about to become engaged in some criminal scheme unrelated to the case in which the lawyer represents him, may supply information (indeed, should supply information) to the government about the scheme without giving up the professional position from which she perceives it. Thus, for example, a lawyer who visits the client's warehouse in the course of preparing a defense in a case of tax evasion and while there learns that the client is engaged in a major drug smuggling operation may inform the government, and continue to do so for some period, without resigning from the tax case. The hard question, then, has no simple answer.

The hard answer might depend upon the point in the representation where the client has a manifest adversary interest that might be jeopardized by the lawyer's divided loyalty. I am thinking of that period, often protracted, when both parties are separately preparing their cases, or more likely, just sitting and waiting as the case slowly, imperceptibly matures, rising on the docket until it approaches close enough to "ready" that the parties begin serious interactive trial preparation. Representation during this inactive phase, it seems to me, is not compromised by the lawyer's divided interest. But the moment counsel is called upon to engage with her adversary, filing pretrial motions, negotiating a plea, or (of course) starting the trial, sensitive interests of the

infiltration may be undertaken at government option.

B6 Conceivably, some might go further than $I$ and argue that when a client solicits her lawyer's participation in crime, she waives all entitlement to professional loyalty; the privilege dissolves and the lawyer is free to inform on any matters as his conscience or self-interest directs, including communications relating to the pending case that would otherwise be clearly "secrets" or "confidences" under DR 4-101(A). 
client are on the line, and the conflicted attorney becomes disqualified to pursue them.

It is not easy to discern from the record just when that moment occurred between Glass and Ofshe, but it is indisputable that Glass overstayed his welcome. Thus Glass, the principal, as a lawyer under suspicion, reporting to the government about his client's crimes, remaining active as counsel while his client's substantial interests were in negotiation, was professionally derelict.

\section{Accessorial Responsibility}

Having concluded that Glass labored under an unethical conflict of interest, we arrive at the second major question: by what line of reasoning or authority is his dereliction to be attributed to Turow? It is possible, of course, that an ethical violation might be committed by conduct analogous to accessorial behavior in the law of crimes. It is not, however, an irresistible transposition. The criminal culpability of the accessory has long been a matter of considerable discussion and most modern codes meticulously set forth the nature of culpable assistance before ${ }^{57}$ and after a crime, ${ }^{38}$ as well as the degree of culpability attributable to the accessory. Both text and tradition are mute in the area of professional responsibility. It may be unjust, as well as unwise, to assume that the principles of criminal culpability are incorporated by non-reference in the code of ethics.

On the other hand, perhaps the concept of principal and accessory is so deeply ingrained in the minds of lawyers that we regard it as implicit in matters of joint participation. Thus, a lawyer might assume that if lawyer A actively induces lawyer B to reveal the privileged communications of the latter's client, knowing the disclosure to be a breach of B's obligation and desiring that result, A shares responsibility for B's breach. Our common assumption might be reversed, however, if we think of lawyer $\mathrm{X}$, the publisher of a magazine, who listens to the unprivileged story lawyer $\mathrm{Y}$ brings him of her notorious client's pending litigation and offers $\mathrm{Y}$ a contract to do an article about it for the magazine if she can make the necessary arrangement with the client to ob-

57 Technically, "[a]n accessory before the fact is one who orders, counsels, encourages, or otherwise aids and abets another to commit a felony" including one who gives aid toward the commission of an offense at another's request. W. LAFAvE \& A. ScoTT, supra note $49, \S 6.6(\mathrm{c})$.

${ }^{58}$ See Model Penal Code $\S 2.06(3)$ (1985) (defining an accomplice); comment 6(b) (declaring that $\S 2.06(3)(a)$ does not require the accomplice to know of the criminality of her conduct, only to have as her purpose the promotion or facilitation of the conduct that the Code has declared to be criminal). 
tain the publication rights. Here the attribution seems more problematic notwithstanding the clear breach of DR $5-104(B)^{59}$ by lawyer $Y$ if she does as $\mathrm{X}$ proposes. Perhaps the nature of the induced breach is more apparent or grievous with $\mathrm{A}$ and $\mathrm{B}$ than with $\mathrm{X}$ and $\mathrm{Y}$; perhaps the nature of the inducement or the unprofessional intent of the accessory is different. But I suspect that, notwithstanding the "intuitive" assimilation of accessorial percepts, we would require an articulated basis before assuming that all forms of encouragement to all forms of ethical breaches entail attributed responsibility.

Reluctance to deem accessorial responsibility implicit and pervasive in the Code should be fortified by the facts in the Turow-Glass interaction. The prosecutor did not solicit, much less importune, the cooperation of the lawyer. The most the Court of Appeals could suggest was encouragement. And, of course, the government provided the equipment with which Glass could preserve the disclosure of his client (and, incidentally, with which the government could assure itself of the veracity of the interested informant). Again, the record is less than full, but nothing appears to indicate that the encouragement amounted to an offer Glass could not refuse. ${ }^{60}$ At most, it appears that the United States Attorney accepted Glass's tender and listened to the reports and the recording he produced.

Whether this sort of understanding would infect Turow with Glass's guilt had the latter's conduct been criminal seems less than clear to me, but more knowledgeable colleagues assure me that any encouragement amounts to solicitation and providing the body recorder, an instrument of the crime, constitutes aiding and abetting. Granting the point, however, does not affect my conclusion that Turow bears no vicarious responsibility for Glass's professional misconduct. Three features of the cases sever it from the lawyer's common assumption of imputed responsibility implicit in the Code: the weakness of the inducement, the unforeseeability of an ethical breach by the principal, Glass, and the absence of either intention or neglectful neutrality on the part of the accessory, Turow, concerning the occurrence of the culpable conduct.

As indicated, the role of the government in Glass's betrayal was largely passive. The United States Attorney in Chicago, engaged in a

69 "Prior to conclusion of all aspects of the matter giving rise to his employment, a lawyer shall not enter into any arrangement or understanding with a client or a prospective client by which he acquires an interest in publication rights with respect to the subject matter of his employment or proposed employment." MODEL CODE OF PROFESSIONAL RESPONSIBILITY DR 5-104(B) (1982).

Bo In fact, a letter from the United States Attorney informed Glass that he could expect no special consideration with regard to criminal charges against him. 
major investigation concerning corruption of bench and bar, was hardly interested in Glass's exposure of drug deals in Florida. The encouragement must have been minimal. The body recorder, though used to preserve one of Glass's conversations with Ofshe, was hardly an instrument that enabled or facilitated the conflict of interest that was the gravamen of Glass's "crime." Thus, I think it fair to say that, notwithstanding technical complicity under doctrines of criminal law, at the level of Turow's participation, vicarious responsibility for procuring or abetting would seem unjust.

As to the second factor, responsibility should be imputed to an accessory only where the accessorial conduct seems reasonably likely to result in, assist in, or cover up conduct by the principal that the accessory perceives to be illegal or wrong. For all the reasons argued above, a lawyer-even a lawyer under suspicion-who reports his client's criminal plans to the government does not necessarily act wrongfully. Also, as argued below, Turow could not have been expected to foresee, from the point of his participation, what became Glass's unethical representation of his client.

Fortifying the second point and establishing the third, record facts refute any suggestion that Turow intended to encourage unethical conduct by Glass, or was indifferent to whether Glass abided by ethical constraints. He twice instructed Glass to take care that none of his client's secrets and confidences concerning the case in litigation were revealed; he instructed Glass that, at the conclusion of the brief investigation, Glass would have to withdraw as the subject's co-counsel; he received reliable-albeit false-information (from Glass himself, relayed by the FBI) that the prosecution of Ofshe had been dismissed (and, presumably Glass's representation of Ofshe on that matter terminated by the same stroke) before Glass recorded the conversation with Ofshe; at the first opportunity following his discovery that the case was still alive and Glass still actively representing Ofshe, Turow disclosed Glass's disqualification to the judge presiding in the Ofshe matter and insisted on Glass's withdrawal. These facts are inconsistent with a finding that Turow harbored the culpable intent requisite to the attribution of vicarious responsibility.

The Court of Appeals may have had in mind some special responsibility of a public prosecutor to refrain from any role whatever in any arrangement wherein attorneys might be compromised in their professional relationships. This may or may not be a good precept for the prosecutors, but it is far from any command, articulated or implicit, in the existing body of law. Neither the Code, the Standards, nor the professionally understood principles derived from criminal doctrines of ac- 
cessorial responsibility imply such duty. Like the Court of Appeals, I can think of a number of restraints I would impose on public prosecutors that are nowhere suggested in the current law. Unlike the Court of Appeals, however, I would not publicly accuse a lawyer of the violation of any imaginary provision.

\section{B. As to the crime}

Problematic as the Court of Appeals' recommendation of disciplinary action against Scott Turow may be, the truly astonishing feature of the unpublished opinion is its theory of criminality, reinforced by an invitation to indictment directed to the local United States Attorney. ${ }^{61}$ As the Court expresses it, Turow should have anticipated (and therefore specifically intended) that by enlisting Glass as a government informant the "due administration of justice" would be impeded by a "waste of scarce judicial and parajudicial resources," i.e., time. Needless continuances seem to be the essence of the offense thus defined.

At one point the court approaches a somewhat grander theoretical foundation for its conclusion. "In effect," they write, "Turow and Glass are responsible for an involuntary waiver by Ofshe of his right to the effective assistance of counsel. Corruptly coercing a defendant to waive a constitutional right during a judicial proceeding violates section 1503."62 The coercion, presumably, was found in the agreement between Glass and the government not to inform Ofshe that his lawyer was cooperating in an investigation against Ofshe. Such deliberate concealment, even if it might be termed fraud, falls somewhat short of the standard meaning of coercion and, in any event, hardly generates a

61 The fact that Turow was acting pursuant to the official approval of his office not only makes his prosecution unlikely, it argues against criminality. The Supreme Court has recognized the unfairness of criminally punishing conduct approved by government agencies. See United States v. Laub, 385 U.S. 475, 487 (1967) ("[o]rdinarily, citizens may not be punished for actions undertaken in good faith reliance upon authoritative assurance that punishment will not attach."); see also United States v. Pennsylvania Chem. Corp., 411 U.S. 655, 674 (1973) (Appellants were entitled to raise as a defense to a charge of discharging industrial pollutants into a navigable river that they relied on Corps of Engineers regulations as "their designed purpose was to guide persons as to the meaning of the statute."), Cox v. Louisiana, 379 U.S. 559, $569-71$ (1965) (Demonstrators could not be convicted under a state statute prohibiting demonstrations near a courthouse when "the highest police officials of the city, in the presence of the Sheriff and Mayor, in effect told the demonstrators that they could meet where they did."), Raley v. Ohio, 360 U.S. 423, 425-26 (1959) (Since the "Un-American Activities Commission" of Ohio had assured the appellants that they had a privilege against selfincrimination, the state could not then convict them for refusing to answer the questions as to which the privilege was claimed.).

${ }_{62}$ Ofshe, at 11. The court cites United States v. Silverman, 745 F.2d 1386, 1395 (11th Cir. 1984). The authority is totally inapposite. See supra notes 19,48 and accompanying text. 
"waiver," voluntary or otherwise, as the court supposed. Moreover, the conclusion overlooks the explicit stipulation by the government that Glass would not continue to represent Ofshe beyond that conclusion of the investigation.

But apart from these oddities, the passage raises an interesting question regarding the intersection of the Code of Professional Responsibility and the criminal law. The court found, after all, that the arrangement between Glass and Turow caused no substantial harm to Glass's sixth amendment rights to effective legal assistance. Thus, the right that Turow caused Ofshe involuntarily to waive must have been the right derived from the Code, not the Constitution, to Glass's loyal and unconflicted service. By this reasoning-although the court does not say as much-Glass, as well as Turow, committed the crime of obstruction of justice by undertaking professional employment in conflict with his personal interests, thereby risking the expenditure of time to rectify possible (though unrealized) harm to his client's right to counsel's undivided loyalty.

The enforcement of the professional proscriptions by criminal sanctions must at least give us pause. Or, to put it the other way, filling in the spaces in a loosely worded criminal statute by incorporating the tenets of a code of professional ethics raises interesting questions concerning the delegation of legislative authority to professional associations. ${ }^{83}$

Not only does the court's theory of the crime distort its shape and character, but the means employed to explain Turow's culpability are crude and unconvincing. To demonstrate the foreseeability of the "natural and probable consequence" of the prosecutor's "scheme", the court lays out three "scenarios" of possible outcomes. To make the point, the court must mean these to be the only, or at least the most likely, results of the arrangement between Glass and Turow. Yet a moment's reflection will produce an equal number of equally likely consequences having only negligible impact on the scarce judicial or "parajudicial" resources the court so earnestly endeavors to protect.

Perhaps the most obvious alternate "scenario" (as well as the closest to the outcome actually anticipated by the prosecutor) would be a limited period of reporting and recording during the vacant weeks (or months) of pretrial stasis during which nothing was done in Ofshe's behalf (except possibly by Black who was to try the case). During this lull, Ofshe's efforts to enlist Glass in a drug deal and to introduce Glass

${ }^{63}$ For a brief overview of the legal effects of professional codes, see generally Lind \& Ullberg, Are Professional Codes of Ethics Acquiring the Force of Law?, 11 A.L.I.A.B.A. Course Materials Journal, June 1987, at 63-90. 
to his buddies who needed their money laundered were the principal matters between them. Then, as the time for plea negotiation approached, Glass would resign, perhaps for a feigned reason. Black, presumably familiar with the facts of the case as well as its triability, surely could undertake the plea discussions himself, or if he brought in a new emissary to substitute for Glass, little time would be needed to charge him with his mission and send him off to talk to the United States Attorney.

Another likely scenario, which Turow might have anticipated under the heading "nothing ever goes as it should," would be that Glass's perfidy is quickly discovered by the Ofshe camp and he is unceremoniously booted off the defense team. This development might generate some concern for their erstwhile informant's health and wellbeing, but the U.S. Attorney would have little reason to fear for the prompt dispatch of the proceedings in Florida by reason of this contretemps.

A third eventuality is that Glass stays aboard too long and participates in the client's case in some ways incompatible with the client's right to undivided loyalty. With prescience, the prosecutor might have anticipated the plot that eventually unfolded. Taking it at its worst, the prosecutor might have imagined that Glass would suggest adjournments to co-counsel on feigned grounds to allow him to pick up some additional information for the government file. Or Glass might even induce the client to tender a spurious offer of cooperation in exchange for a conditional dismissal of the indictment. Granted that this possible outcome might require some continuances not otherwise necessary, it is far from clear that time is "wasted" by reason of the government's conduct. First, adjournments of pending cases to allow the government time to pursue related investigations are commonplace and, to my knowledge, never challenged as impeding the administration of justice. Second, the effort by Glass to "turn" his client, though it came to naught, can hardly be termed obstructing justice notwithstanding some delay in the disposition of the matter by reason of Ofshe's disappointing performance.

These equally likely scenarios inconsistent with the court's notion of the heart of the crime- unwarranted calendar delay-fatally undermine one essential prop supporting the court's theory: a reasonably foreseeable impediment. The second weakness in the court's invitation to indictment is the inherent improbability of the scenarios selected by the court.

The first scenario submitted by the court is a masterpiece of sophistry. From a conjectural base that Glass's motion to withdraw on 
fabricated grounds would be denied, the court concludes, two sentences later, that Turow corruptly coerced Ofshe to waive his constitutional right to counsel. In addition to the alarming leaps in inference, the court assumes that the prosecutor would remain inert when the lawyer failed to withdraw. Even the ingredient detail of the scenario ignores actual occurrences. Far from "coercing" the defendant to accept conflicted counsel (further still from "corrupt" coercion), Turow revealed the lawyer's conflict to the District Court for appropriate protection of Ofshe's rights.

As to the second of the court's scenarios, it was extremely unlikely that Black, who knew nothing of Glass's arrangement, would be disqualified, so the "burden" on the court of waiting for new counsel to get up to speed is highly conjectural. The third scenario appears to mimic the actual outcome, until it unaccountably veers off and allows Glass to continue as counsel into the trial itself. If the conflict were first discovered during, or worse still after the trial, serious judicial inefficiency might well be the cost. But there is no reason to guess, much less to expect that Turow would have allowed things to reach that stage without himself stepping in.

Surely the fatal flaw in the opinion of the Court of Appeals (as well as its most alarming aspect) is in its view of the nature of the crime of obstruction of justice. The idea that a prosecutor's decision, taken in the proper exercise of his official responsibility to uncover as well as prosecute crime, could be a criminal obstruction of justice if it results in some delay in the prosecution of some other case is incomprehensible. Prosecutors regularly postpone the prosecution of charges against a defendant who they expect will be a witness in the prosecution of some other case. Codefendants are severed and the government chooses one to try first while the others wait their turn. Cases are continued to allow an undercover officer to complete an investigation before her "cover is blown." Dozens of other examples could be cited of law enforcement purposes taxing the judicial interest in expedition.

It is a familiar balance of interests which frequently favors law enforcement. As it should. Within broad limits, the importance of a diligent investigative law enforcement agency clearly outweighs the ephemeral considerations of calendar efficiency, such as it is. The court's theory of the crime is so distant from any prior use of the statute that it virtually amounts to amendment of the statute. Moreover, the idea that legitimate efforts of law enforcement lawyers to pursue promising leads, to develop new cases, even at some minor consequent cost to docket efficiency, amounts to a criminal obstruction of justice is so bizarre that one can only hope one has misunderstood the plain import of 
the Court of Appeals' opinion.

\section{The Status of the Matter}

Unless Turow is indicted (which seems unlikely in light of the role of the Department of Justice in the matter ${ }^{64}$ ) or censured by the grievance machinery (which has not yet occurred) he is without recourse. Instructed by experience, he will surely not petition the same court for reargument, and en banc review seems highly unlikely. The issue is hardly suitable for the Supreme Court's crowded docket. So, without notice, without an opportunity to be heard, and without access to a reviewing tribunal, Turow's professional reputation is impugned for lawful behavior, in accord with the policy of his office and the Department of Justice, undertaken in the interests of law enforcement. In effect, a panel of the Gourt of Appeals for the Eleventh Gircuit sat as a grand jury, voted a true bill, and Turow, without a trial forum, will be forever presumed guilty. ${ }^{65}$

${ }^{64}$ As this article went to press, the Department of Justice informed $\mathrm{Mr}$. Turow that the matter would not be presented to a grand jury. See letter on file with the University of Pennsylvania Law Review. The Department reaffirmed its position that Turow had done nothing wrong.

${ }^{65}$ In a letter addressed to Mr. Turow's counsel, the Department of Justice stated that, having concluded an investigation, they found "no evidence" warranting prosecution. The letter also reaffirmed their position that Turow had done nothing wrong. See Letter from John C. Keeney, Acting Assistant Attorney General, to Thomas P. Sullivan (April 29, 1988) (copy on file with the University of Pennsyvania Law Review). 
. 